\title{
Studying the Role of Behavioral Characteristics in Individuals Travel Choice Behavior in Response to Earthquake Disaster Using Discrete Choice Models
}

\author{
Fatemeh Mohajeri (iD) and Babak Mirbaha (iD \\ Department of Transportation Engineering and Planning, Technical and Engineering Faculty, \\ Imam Khomeini International University, Qazvin, Iran \\ Correspondence should be addressed to Babak Mirbaha; mirbaha@eng.ikiu.ac.ir
}

Received 28 June 2021; Accepted 27 August 2021; Published 15 September 2021

Academic Editor: Zhibin Wu

Copyright (c) 2021 Fatemeh Mohajeri and Babak Mirbaha. This is an open access article distributed under the Creative Commons Attribution License, which permits unrestricted use, distribution, and reproduction in any medium, provided the original work is properly cited.

\begin{abstract}
The study of decision-making in response to earthquake disaster including evacuation and destination choice behavior is necessary for emergency planners in order to provide emergency traffic management and solve evacuation problems in transportation network. In this research, it is attempted to study the pattern of choice behavior in Qazvin transport network by considering physical and behavioral factors simultaneously. The required data were collected through a questionnaire from 546 inhabitants of Qazvin based on the stated preferences (SP) survey for six designated earthquake scenarios at different severities and times. The effects of socioeconomic factors, trip daily characteristics, and behavioral factors on decisions to evacuate and choose destinations are studied in this research. The binary logit model is applied for analyzing the evacuation decision, and the multinomial logit model is applied for the destination choice in response to the earthquake disaster. The binary logit model analysis with $73 \%$ correct prediction indicates that socioeconomic characteristics including age, marital status, family size, and car ownership have positive effects on evacuation choice. Furthermore, the analysis of behavioral factors indicates that moderate religious belief decreases the likelihood of evacuation, while following previous experiences, trust in acquired trainings, and following decisions made by others moderately increase the likelihood of evacuation. Also, socioeconomic and behavioral factors are the determinants of the destination decision, and the results indicate that individuals following previous experiences highly are more likely to choose gas station and relative's home destination versus going to urban open spaces.
\end{abstract}

\section{Introduction}

Iran is situated in a high seismic region of the Alpine-Himalayan belt and has a long history of earthquake disasters [1]. This fact indicates the importance of preparation to confront earthquake events and reduce its negative consequences [2]. Regarding the effects of the earthquake disaster on the transportation demand, such as unexpected demand in a short term and the chaotic behavior of the urban road users, it is necessary to investigate the trip choice behavior in response to earthquake disaster [3]. Many researchers used preearthquake trip demand for the postdisaster planning and after modifying them, applied for management strategies [4], while, in order to calculate the changes in traffic patterns after the earthquake, due to the destruction of transportation infrastructure, the performance of urban road network should be evaluated after the earthquake [5]. After the earthquake, the damaged parts of network cause extremely congested traffic in the available paths. In addition, unusual traffic demand for unspecified purposes will lead to traffic problems throughout the transportation road network [6]. In order to analyze and predict the postearthquake urban road network situations, it is first necessary to study the behavior of individuals in the situation of an earthquake disaster. Therefore, it is important to discover the factors affecting decision-making of individuals in response to earthquake. Since there are behavioral factors affecting decision-making process in response to earthquake 
disaster [7], it is attempted to study the pattern of choice behavior in Qazvin transport network by considering socioeconomic and behavioral characteristics simultaneously. The main objectives of this research are to study the choice behavior of individuals immediately after the earthquake in the stages of action choice and destination choice, studying how people respond to the earthquake disaster in different severities and times of occurrence and identifying the factors affecting the choice behavior after the earthquake disaster. The required data of this research were collected through stated preferences survey for six designated scenarios of the earthquake occurring at different severities and times in one working day. The questionnaire contains socioeconomic characteristics, the daily trip characteristics, and behavioral factors affecting decision-making in response to the earthquake disaster. The obtained information from this research can be useful in postdisaster planning. In the next section, in order to identify the appropriate variables in decisionmaking process, there is a review of previous studies in this field.

\section{Literature Review}

In recent decades, many researchers studied the choice behavior of individuals in response to emergency situations. The results of postevent studies serve as inputs to predict respondents' behavior. However, for events with high levels of uncertainty, such as hurricanes and earthquakes, it is not always possible to generalize findings from one condition to future events. Instead, preevent studies provide analysis of a wide range of hypothetical scenarios based on various assumptions about the location and severity of the disaster [8]. Many researchers have examined the factors affecting decision-making in response to natural hazards and the factors influencing the travel demand in these situations. Different behavioral models in this regard have been presented. In the following, the studies conducted in the field of decisionmaking in response to natural hazards are examined.

Baker determined the most important factors affecting the choice of emergency evacuation. Baker compared the actual and hypothetical Hurricane evacuation behavior. The results showed that the logistic regression models accurately estimate the actual behavior of the respondents [9]. Whitehead et al. [10] investigated evacuation behavior in North Carolina in the occurrence of hurricanes. They indicate that socioeconomic characteristics including income, education, and gender affect how people respond to disaster by estimating logit model [10]. In the study of Bateman and Edwards, the results show that women are more likely to evacuate than men, because they feel more at risk or feel more responsible to protect children [11]. Dash and Gladwin have examined a wide range of factors that affect evacuation decisions after Hurricane forecasts. The results indicate that gender, age, disability, and income play important roles in evacuation decision-making [12]. Solís et al. determined the individuals' choice behavior in the event of a Hurricane using probit modeling. They found that having children and experiencing past Hurricane increased the likelihood of evacuation [13]. Deka and Carnegie developed logistic regression models to study decision-making in different types of natural and man-made disasters. The results show that the socioeconomic characteristics of the respondents play an important role in Hurricane conditions compared to other emergencies [14]. Richard Eiser et al. [7] proposed a general framework in response to natural disasters in a review study. They believe that risk perception is an effective factor in response to natural disasters. In their research, a review is provided to present a framework for conducting future studies in this area. In their opinion, the perceived risk of disasters that affects the response of an individual depends on factors such as making decisions on the basis of experience, trust in others, and cultural and religious beliefs [7]. Shapira et al. investigated the anticipated behavioral response pattern to an earthquake in Israel, in which personal and household characteristics, risk perception, previous experience, and preparedness are recognized as significant factors on choice behavior [15]. In a study conducted by Lim et al. [16], individuals' decision-making in response to flood using discrete choice models including multinomial logit models was examined in areas with high risk of flood in the Philippines. The results indicate that age, income, home ownership, number of floors, and flood level have a significant impact on people's decisions [16]. Phiophuead and Kunsuwan identified the factors affecting the travel mode choice during evacuation in times of crisis using binary logit model analysis. According to their research, gender, age, family size, education, car ownership, experience of natural disasters, knowing the location of the shelter, and ease of access to the vehicle are among the factors affecting evacuation behavior in crisis situations [17]. As mentioned, researches are mostly based on assumptions about the behavior of people after an earthquake that may not be realistic or applicable in all countries. In order to make it more accurate to predict the choice behavior after the earthquake disaster, it is attempted to investigate the travel behavior of people in response to earthquake with considering the impact of behavioral factors on choice behavior including making decisions on the basis of experience and acquired trainings, trust in others, and religious beliefs. Table 1 presents the summary of selected literature on choice behavior in disasters. As shown in Table 1, researches in the field of method of analysis have been moved from descriptive analysis to discrete choice models. According to the previous researches, the discrete choice modeling framework presented in Train [18] is used in this research.

\section{Methodology}

Individuals' decision-making and response to a disaster are considered in four stages, respectively, including (a) action choice (deciding whether to evacuate or stay in the building), (b) trip mode choice, (c) destination choice, and (d) route choice [19]. In this study, the issue to be analyzed is decisionmaking in two stages: evacuation and destination choice. In order to analyze and predict the condition of urban road network after earthquake, the stated preference survey was used for the designated scenarios of earthquake occurrence in the different severities and times. Factors affecting the 
TABLE 1: Summary of selected literature on choice behavior in disasters.

\begin{tabular}{|c|c|c|c|c|}
\hline Researcher & Year & $\begin{array}{l}\text { Data collection } \\
\text { method }\end{array}$ & Method of analysis & $\begin{array}{l}\text { The most important factor affecting choice behavior in } \\
\text { disasters }\end{array}$ \\
\hline Baker & 1991 & $\mathrm{RP}$ & Descriptive analysis & Risk area, official evacuation orders \\
\hline Whitehead et a. & 2000 & $\mathrm{RP}$ & Logit model & $\begin{array}{c}\text { Socioeconomic characteristics including income, education, } \\
\text { gender }\end{array}$ \\
\hline $\begin{array}{l}\text { Bateman and } \\
\text { Edwards }\end{array}$ & 2002 & $\mathrm{RP}$ & Logit model & Gender, confronting the risk, perception of danger \\
\hline Dash and Gladwin & 2007 & - & Review study & Gender, age, disability and income \\
\hline Solís et al. & 2010 & $\mathrm{RP}$ & Probit model & $\begin{array}{c}\text { Having children, having experience of Hurricane, home } \\
\text { ownership }\end{array}$ \\
\hline Deka and Carnegie & 2012 & SP & $\begin{array}{l}\text { Logistic regression } \\
\text { models }\end{array}$ & Socioeconomic characteristics \\
\hline Richard Eiser et al. & 2012 & - & Review study & $\begin{array}{l}\text { Following previous experiences, values, individual feelings, } \\
\text { cultural beliefs, and social variables }\end{array}$ \\
\hline Shapira et al. & 2018 & SP & $\begin{array}{l}\text { Multivariate logistic } \\
\text { regression }\end{array}$ & $\begin{array}{c}\text { Socioeconomic status, levels of earthquake preparedness and } \\
\text { dwelling type }\end{array}$ \\
\hline Lim et al. & 2019 & $\mathrm{RP}$ & $\begin{array}{l}\text { Multinomial logit } \\
\text { model }\end{array}$ & $\begin{array}{c}\text { Age, income, home ownership, number of floors and flood } \\
\text { level }\end{array}$ \\
\hline $\begin{array}{l}\text { Phiophuead and } \\
\text { Kunsuwan }\end{array}$ & 2019 & SP & Binary logit model & $\begin{array}{c}\text { Gender, age, family size, education, car ownership, experience } \\
\text { of natural disasters }\end{array}$ \\
\hline
\end{tabular}

evacuation choice behavior of individuals and destination choice under 6 earthquake scenarios (including earthquakes with minor, moderate and severe severities in two periods of time; day and night) are studied. The research structure is presented in Figure 1.

3.1. Case Study. Qazvin is one of the important cities in the west and center of Iran. This city has a population of about 750-800 thousand individuals. This city has great importance due to its location in a particular geographical and geological location and the presence of powerful seismic faults and active seismic history and the occurrence of earthquakes in recent years [20]. Figure 2 indicates the area surveyed for assessing the seismicity comprising a circle with a radius of 150 Kilometers from the city.

The strongest recent instrumental earthquake relevant to the city is the event of 20/06/1990 with 7.4 magnitude, at a distance of about $109 \mathrm{Km}$ [21], and the nearest recent earthquake relevant to the city is the event of $20 / 12 / 2017$ with 5.2 magnitude, at a distance of about $130 \mathrm{Km}$. The major faults in the project area are indicated in Figure 2. The North Qazvin Fault was identified as major active fault in the north of the Qazvin city, and the ESHTEHARD Fault and IPAK Fault were identified as major active faults in the south of the Qazvin city. As the Qazvin city is not very extended in terms of area, devastating impact of earthquakes in all areas of the city is assumed to be the same. Figure 3 indicates the road network of Qazvin city.

3.2. Data Collection and Questionnaire Designation. A questionnaire is designed to study the factors affecting the trip choice behavior of individuals in response to earthquake disaster in Qazvin city. The questionnaire was developed according to the key information obtained from the pilot survey of 60 respondents. The designated questionnaire consists of 4 sections, including (1) the socioeconomic characteristics of individuals including gender, age, education, marital status, and occupation [17]; (2) the characteristics of individuals' daily trips including the purpose of daily trips, the geographical location of daily trips, traffic conditions, and familiarity with alternative routes in daily trips [23]; (3) the behavioral factors affecting decision-making using the variables presented in the paper by Richard Eiser et al. [7], including past experiences in decision-making, cultural and religious beliefs, trust in acquired trainings, and decisions made by others [7]; and (4) the six different designated scenarios of earthquake occurrence including three (minor, moderate, and severe) earthquake severity scales in two (day, night) times. Table 2 indicates the six designated scenarios in the questionnaires in terms of three severity scales and two times of the earthquake occurrence.

Since it is not possible to investigate the whole society because of time and budget constraints, statistical sample should be analyzed. Inadequate numbers of statistical samples cause unreliable results. The Cochran formula is one of the most commonly used methods for calculating sample size [24]. For 381598 statistical population of the Qazvin, the 95\% level of confidence, the minimum required sample size according to Cochran formula is 384 . In order to increase the validity of the modeling, more samples were studied. Using data obtained from the Qazvin Central Bureau of Statistics, a random sample with different socioeconomic levels that is distributed all over the city was surveyed. The sample included adult representative (at least 18 years of age). Previously trained field surveyors distributed the survey door to door according to predefined, randomly selected addresses within each census tract. Sampling was performed randomly from residents in different regions of Qazvin city. Also, the individuals for data collection were chosen from employees, university students, clients of health centers, customers of gas stations, and businesses in different geographical areas of Qazvin. The number of questionnaires that have been fully completed by the respondents and used for analysis is 546 questionnaires. In order to assess the reliability 


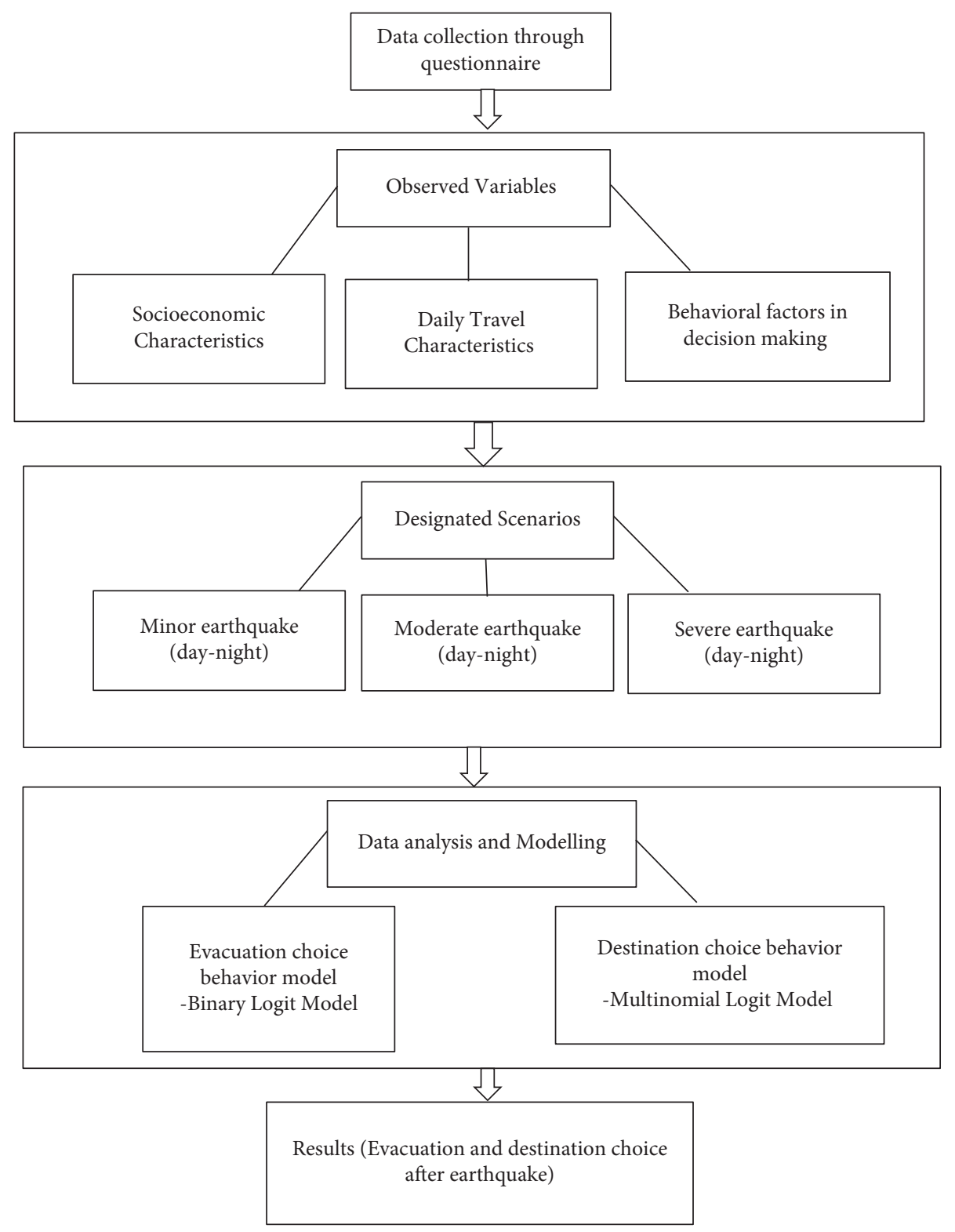

Figure 1: Structure of methodology.

of the questionnaires, Cronbach's $\alpha$ coefficient $(0.721)$ is also estimated. Since the value of this coefficient is more than 0.7 , the questionnaire reliability can be approved [25]. Evacuation and destination choice modeling in response to earthquake disaster are challenging due to the shortage of evacuation data. Destination choice decisions are important for emergency planners to estimate the demand. The choice stages and their alternatives in response to the earthquake are presented in Table 3.

3.3. Discrete Choice Model. Discrete choice models basically postulate that an outcome is selected if the utility is higher than any other outcome. The advantage of this method is its simplicity and closed form estimation, in addition to its ability to capture behavioral context of the decision-making [16]. In the discrete choice models, a utility function is used to define the individual preferences for choosing an alternative. The value of the utility is typically used to compare different alternatives. In a choice set, an alternative with a higher utility value is more likely to be chosen [19]. Equation (1) was used to quantify the utility based on two terms: (1) the deterministic component and (2) the random component. First, the deterministic component $\left(V_{i n}\right)$ represents a set of individuals capable of providing all the required information for each alternative, and their preferred alternative. Second, the random component $\left(\varepsilon_{i n}\right)$ indicates the uncertainty in making a decision. Equation (2) shows the associated parameters and factors to calculate $U_{i n}$.

$$
\begin{aligned}
& U_{\text {in }}=V_{\text {in }}+\varepsilon, \\
& V_{\text {in }}=\beta_{0}+\beta_{1} x_{1}+\beta_{2} x_{2}+\cdots+\beta_{n} x_{n},
\end{aligned}
$$




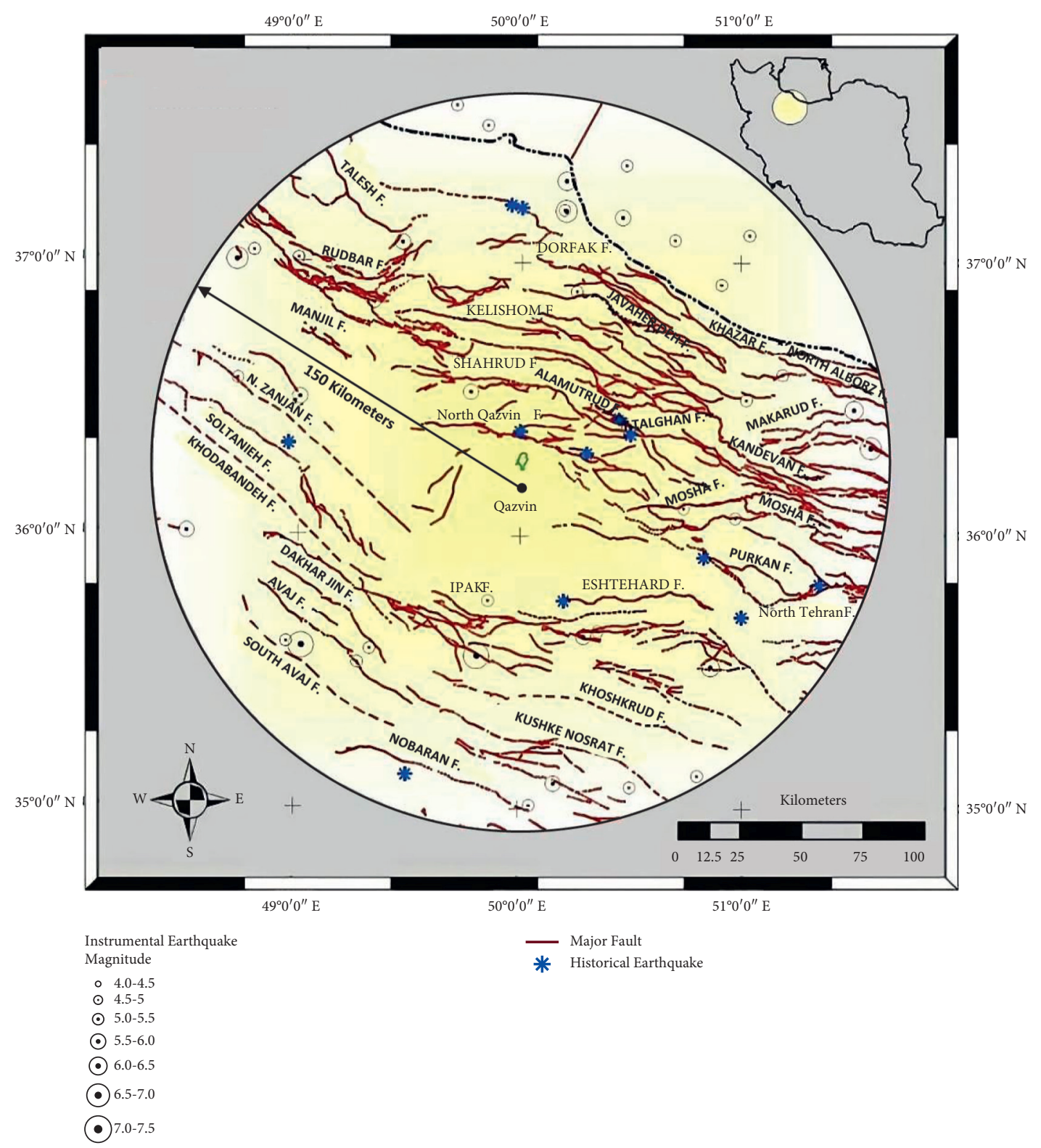

Figure 2: Seismotectonic map within a radius of 150 kilometers around the city [21].

where $U_{i n}$ is the utility of person $n$ choosing alternative $i ; V_{i n}$ is the deterministic component of utility; $\varepsilon$ is the random component of utility. $\beta_{0}$ is the model constant; and $\beta_{1}, \ldots, \beta_{n}$ are the parameters corresponding to the explanatory factors $\left(x_{1}, \ldots, x_{n}\right.$ the set of independent factors). These parameters were estimated using logistic regression analysis. Equation (3) is used to estimate the probability of decision-making, where $U$ is the utility function of each alternative, and the unknown parameters $\beta_{1}, \ldots, \beta_{n}$ in Equation (2) are estimated using maximum-likelihood methods [18].

$$
P_{n(i)}=\frac{e^{U_{i n}}}{e^{U_{i n}}+e^{U_{j n}}} .
$$

After reviewing previous researches, it can be concluded that the complexity of the individual's behavioral response to the disaster originates from the complexity of factors affecting hazard cognitions and motivate protective behavior. The behavioral choice is crucial in the study of responses to potential disasters. Investigating the results of researches on factors affecting response to disaster indicates that the role of behavioral characteristics in response to earthquake disaster is neglected in previous studies. Therefore, in this study, the role of behavioral characteristics is investigated in response to earthquake disaster. This study attempts to analyze the variables affecting individuals' choice behavior, by addressing possible scenarios in different times and severities of earthquake and analyzing the results based on the stated preference data and discrete choice modeling.

To study the choice behavior of individuals in the urban road network in response to the earthquake disaster, discrete choice models have been applied as mentioned in the 


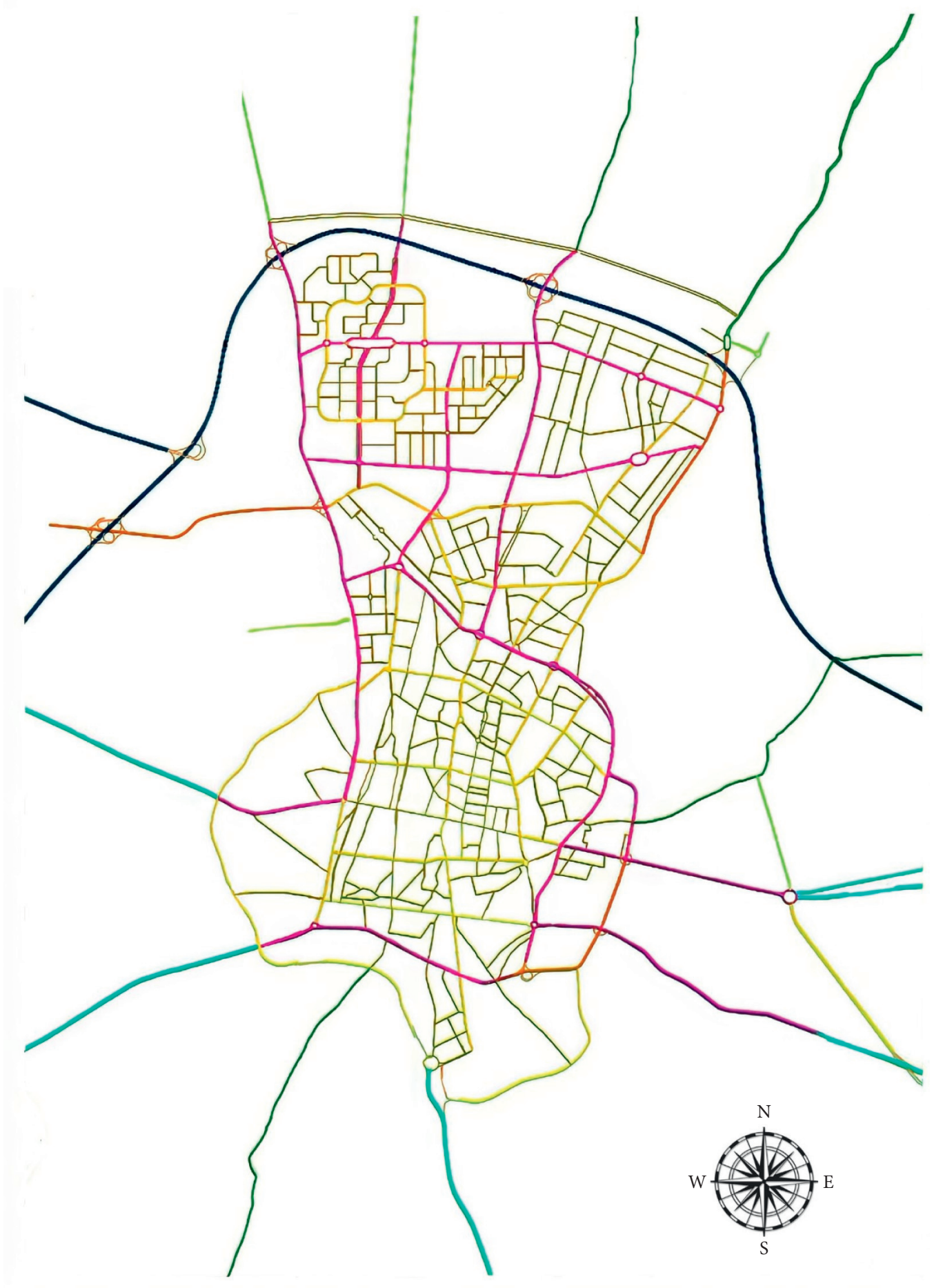

Guide:
- Freeway
— Expressway
- The main routs By-way Rural road
— Collector and distributor
_ Ramp and Loop

FIgURE 3: The Qazvin road network [22]. 
TABLE 2: Designated scenarios in the questionnaire.

\begin{tabular}{lcc} 
& Earthquake severity scale & Earthquake time \\
\hline Scenario 1 & Minor & Day \\
Scenario 2 & Minor & Night \\
Scenario 3 & Moderate & Day \\
Scenario 4 & Moderate & Night \\
Scenario 5 & Severe & Day \\
Scenario 6 & Severe & Night \\
\hline
\end{tabular}

Minor (3-4.9 Richter): these earthquakes, in addition to being recorded by seismic devices, are also felt by humans but do not result in significant losses and destructions. Moderate (5- 6.9 Richter): this class of earthquakes usually damages the buildings and other urban structures. All the people feel it, the cabinets and heavy objects move in the house, the car's control becomes harder to drive, the houses collapse, and some fall under the rubble. Severe (7-7.9 Richter): this class of earthquakes causes mass casualties and damages the urban buildings and structures, especially in developing cities and countries. Day: a period of time that individuals are usually awake: from 7:00 AM to midnight. Night: a period of time that individuals are usually sleep: from midnight to 7:00 AM.

TABle 3: The choice stages and their alternatives in response to the earthquake.

\begin{tabular}{lcc}
\hline Stage & Alternatives & $\begin{array}{c}\text { Name of } \\
\text { variable }\end{array}$ \\
\hline $\begin{array}{l}\text { The action choice in response to earthquake crisis (in time of the } \\
\text { earthquake occurrence) }\end{array}$ & $\begin{array}{c}\text { Leaving the building and going out (evacuation }=1, \\
\text { not evacuation }=0)\end{array}$ & Evacuation \\
\hline & Existing gas stations of the city & $\begin{array}{c}\text { Destination1 } \\
\text { Destination2 }\end{array}$ \\
The destination choice & $\begin{array}{c}\text { Service and relief centers } \\
\text { Relatives' homes }\end{array}$ & $\begin{array}{c}\text { Destination3 } \\
\text { Destination4 } \\
\text { Destination5 }\end{array}$ \\
\hline
\end{tabular}

literature review. Regression analysis is a statistical method to exploit independent variables and model the relationship between dependent and independent variables. Logistic regression model is an improved regression applied for dichotomous dependent variables [26]. In order to examine the effect of independent variables on the decision-making, binary logit and multinomial logit models were used. The binary logit model is a choice probability model that uses the evacuation decision as the dependent variable. A choice of an evacuation is coded as 1 , and a choice of no evacuation is coded as zero. The evacuation destination probabilities are estimated with the multinomial logit model. The multinomial logit model particularly is used when there are more than 2 outcomes. Modeling was performed by Nlogit software in order to predict discrete events, and also to identify descriptive variables and their relation with the occurrence of events and eventually an estimate of the occurrence probability of an event for a particular individual.

3.4. Data Analysis and Modeling. In order to investigate the travel choice behavior pattern of individuals in response to earthquake disaster, according to the surveys and variables considered in previous studies, the variables in this research used for modeling are defined in Table 4.

Before examining the results of modeling, in order to ensure proper distribution of the explanatory variables, their frequency was statistically studied. The frequency distribution diagrams of the age, gender, marital status, and level of education are indicated in Figures 4-7. The statistical analysis indicated that 294 respondents were male and 252 were female. The respondents in the age group of 25-32 and bachelor's degree education had the highest frequency percentage. Also $62 \%$ of respondents were married.

In order to investigate the choice behavior in response to the earthquake disaster including evacuation choice and also the trip destination choice, the frequency percentages of dependent variables are analyzed and indicated in Figures 8 and 9. The analysis of the results indicates that $46 \%$ of people tend to evacuate. In terms of the trip destination, going to the urban open spaces has the highest frequency percentage.

For studying the response of individuals to earthquake disaster in the situation of each designated scenario, each scenario is defined with three severity scales and two times of the earthquake occurrence. These variables are defined in Table 4 with these symbols: "Minor," "Moderate," "Severe," and "Time." These variables are defined as dummy variables, and each dummy variable represents one category of the explanatory variable and is coded with 1 if the case falls in that category and with 0 if not. Table 5 indicates the view of the database for describing designated scenarios. For example, as shown in Table 2, scenario 1 is defined with "Minor" severity of earthquake in the time of "Day." Scenario 1 is defined with ("Minor" $=1$, "Moderate" $=0$, "Severe" =0, and "Time" =0) in the database (Table 5). Also, as shown in Table 2, scenario 6 is defined with "Severe" severity of earthquake in the time of "Night." Scenario 6 is defined with ("Minor" $=0$, "Moderate" $=0$, "Severe" $=1$, and Time =1) in the database (Table 5). To study the effect of six designated earthquake scenarios at different severities (minor, moderate, and severe) and times (day, night), the estimated coefficients of the "Minor," "Moderate," "Severe," and "Time" variables in the binary/multinomial logit models are interpreted. 
TABLE 4: Independent variables of modeling.

\begin{tabular}{|c|c|c|}
\hline Variable & Explanatory variable name/symbol: explanation & Variable type \\
\hline Gender & GENDER & Dummy variable \\
\hline Marital status & Marital status & $\begin{array}{c}\text { Dummy variable } \\
(\text { married }=1, \text { single }=0)\end{array}$ \\
\hline Age & $\begin{array}{l}\text { AGE1: } 18-24 \text { years, AGE2: } 25-32 \text { years, AGE3: } 33-45 \text { years, AGE4: } \\
\text { 46-55 years, AGE5: 56-69 years, AGE6: +70 years }\end{array}$ & $\begin{array}{l}\text { Dummy variable }(\text { Yes }=1 \text {, } \\
\text { No }=0)\end{array}$ \\
\hline Education & EDU1: Diploma and below, EDU2: Bachelor, EDU3: Master, EDU4: Doctorate & $\begin{array}{l}\text { Dummy variable }(\text { Yes }=1 \text {, } \\
\text { No=0) }\end{array}$ \\
\hline Job & $\begin{array}{l}\text { JOB1: Employee, JOB2: Manager, JOB3: Self-employed, JOB4: Doctor, JOB5: } \\
\text { Faculty member, JOB6: Student, JOB7: Housewife, JOB8: Retired, JOB9: } \\
\text { Jobless, JOB10: Other }\end{array}$ & $\begin{array}{l}\text { Dummy variable }(\text { Yes }=1 \\
\qquad \text { No }=0)\end{array}$ \\
\hline Home ownership & Home ownership & $\begin{array}{l}\text { Dummy variable }(\text { Yes }=1 \text {, } \\
\text { No=0) }\end{array}$ \\
\hline Number of family members & FNUM & Numerical variable \\
\hline $\begin{array}{l}\text { Number of cars in each } \\
\text { family }\end{array}$ & CARNUM & Numerical variable \\
\hline $\begin{array}{l}\text { Access to vehicle at } \\
\text { emergency situations }\end{array}$ & $\begin{array}{l}\text { CARUSE1: Not possible access, CARUSE2: Possible (access to vehicle as a } \\
\text { driver), CARUSE3: Possible (access to vehicle as an occupant) }\end{array}$ & $\begin{array}{l}\text { Dummy variable }(\text { Yes }=1 \\
\text { No }=0)\end{array}$ \\
\hline Purpose of daily trips & $\begin{array}{l}\text { Trip purpose1: Education, trip purpose2: Work, trip purpose3: Entertainment, } \\
\text { trip purpose4: Shopping, trip purpose5: Personal affairs, trip purpose6: Other }\end{array}$ & $\begin{array}{l}\text { Dummy variable }(\text { Yes }=1 \\
\text { No }=0)\end{array}$ \\
\hline $\begin{array}{l}\text { Geographical location of } \\
\text { daily trips }\end{array}$ & North: Northern parts, Central: Central parts, south: Southern parts & $\begin{array}{l}\text { Dummy variable }(\text { Yes }=1 \\
\text { No }=0)\end{array}$ \\
\hline $\begin{array}{l}\text { Traffic condition in daily } \\
\text { trips }\end{array}$ & $\begin{array}{c}\text { Traffic1: Very congested, Traffic2: Congested, Traffic3: Normal, Traffic4: } \\
\text { Uncongested, Traffic5: Very uncongested }\end{array}$ & $\begin{array}{l}\text { Dummy variable }(\text { Yes }=1 \\
\text { No }=0)\end{array}$ \\
\hline $\begin{array}{l}\text { Familiarity with alternative } \\
\text { routes }\end{array}$ & $\begin{array}{l}\text { Familiar1: Completely unfamiliar }(\leq 5 \%) \text {, Familiar2: Unfamiliar }(5 \%-20 \%) \text {, } \\
\text { Familiar3: Normal }(20 \%-50 \%) \text {, Familiar4: Familiar }(50 \%-80 \%) \text {, Familiar5: } \\
\text { Completely familiar }(\geq 80 \%)\end{array}$ & $\begin{array}{l}\text { Dummy variable }(\text { Yes }=1 \text {, } \\
\text { No=0) }\end{array}$ \\
\hline $\begin{array}{l}\text { Adherence to previous } \\
\text { experiences }\end{array}$ & $\begin{array}{c}\text { Experience1: None, Experience2: Low, Experience3: Moderate, Experience4: } \\
\text { High, Experience5: Very high }\end{array}$ & $\begin{array}{l}\text { Dummy variable }(\text { Yes }=1 \text {, } \\
\text { No=0) }\end{array}$ \\
\hline Religious beliefs & $\begin{array}{c}\text { Religious 1: None, Religious2: Low, Religious3: Moderate, Religious4: High, } \\
\text { Religious5: Very high }\end{array}$ & $\begin{array}{l}\text { Dummy variable }(\text { Yes }=1 \text {, } \\
\text { No }=0)\end{array}$ \\
\hline $\begin{array}{l}\text { Adherence to the acquired } \\
\text { trainings }\end{array}$ & $\begin{array}{c}\text { Training1: None, Training2: Low, Training3: Moderate, Training4: High, } \\
\text { Training5: Very high }\end{array}$ & $\begin{array}{l}\text { Dummy variable }(\text { Yes }=1 \text {, } \\
\text { No }=0)\end{array}$ \\
\hline $\begin{array}{l}\text { Following decisions made } \\
\text { by others }\end{array}$ & $\begin{array}{l}\text { Follow1: None, Follow2: Low, Follow3: Moderate, Follow4: High, Follow5: } \\
\text { Very high }\end{array}$ & $\begin{array}{l}\text { Dummy variable }(\text { Yes }=1 \\
\text { No }=0)\end{array}$ \\
\hline Earthquake severity & $\begin{array}{l}\text { Minor: Minor severity of earthquake, moderate: Moderate severity of } \\
\text { earthquake, severe: Severe severity of earthquake }\end{array}$ & $\begin{array}{l}\text { Dummy variable }(\text { Yes }=1 \\
\text { No }=0)\end{array}$ \\
\hline Time of earthquake & Time & $\begin{array}{l}\text { Dummy variable (Night }=1 \text {, } \\
\text { Day }=0)\end{array}$ \\
\hline
\end{tabular}

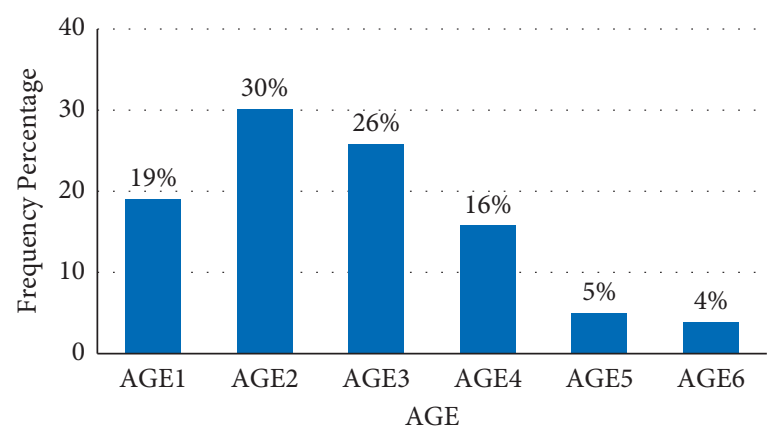

FIGURE 4: Frequency distribution of age variable. 


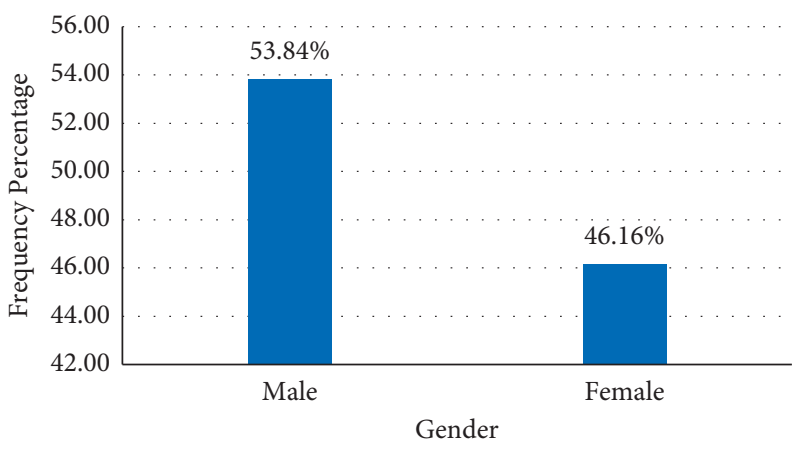

FIgURE 5: Frequency distribution of gender variable.

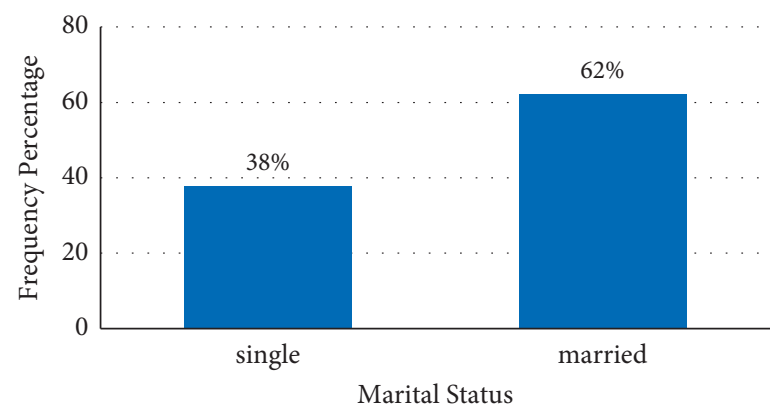

Figure 6: Frequency distribution of marital status variable.

\section{Results}

Further Analyses were conducted by chi-square tests to explore the relationships between the participants' expected choice behavior (evacuation or not; defined as the dependent variable) and other dimensions assessed in the survey (i.e., socioeconomic characteristics, daily trip characteristics, earthquake characteristics, and behavioral factors). In addition, binary logistic regression model is fitted to assess associations of study variables and evacuation behavior. Also, multinomial logistic regression model is fitted to analyze the destination choice dependent variable.

4.1. Analysis the Linear Association of Variables with Nonparametric Statistics. A nonparametric test (sometimes called a distribution free test) is used when there is no assumption about the distribution of the data (for example, the data comes from a normal distribution) in the analysis process [27]. In this study, as the most data retrieved from the questionnaire are nominal and do not have any specified distribution, nonparametric tests are used for the analysis of the linear association of variables. In this study, the choice behavior of participants in response to earthquake disaster is studied in terms of evacuating buildings or not. Associations with nominal independent variables are assessed by conducting chi-square tests. Table 6 indicates the results of nonparametric analysis of socioeconomic/behavioral characteristics. The share of women reporting an intention to evacuate $(52.4 \%)$ is significantly higher than the share of men $(41.5 \%),\left(\chi^{2}=6.46, p=0.011<0.05\right)$. The share of married participants reporting they would evacuate the building if an earthquake occurred (49.7\%) is significantly higher than the share of single ones $(40.02 \%)\left(\chi^{2}=4.431\right.$, $p=0.035<0.05)$; however, this association is rather weak $\left(\varphi_{\mathrm{c}}=0.090, p=0.035<0.05\right)$. The share of participants reporting they would evacuate in the time of night $(68.1 \%)$ is significantly higher than the share of participants reporting they would evacuate in the time of day (31.9\%) $\left(\chi^{2}=3.670\right.$, $p=0.055<0.05)$. For analyzing the association of behavioral factors and evacuation, these variables consider categorical variable with Likert scale. We can use Cramer's V test to strongly understand the association between two variables, because one is a nominal variable, and the other is a categorical variable, and the contingency table is larger than a $2 * 2$ table [28]. The religious belief is significantly associated with choosing evacuation. The share of individuals with low religious belief (Religous2) shows that the probability of evacuations for this group $(60.7 \%)$ is significantly higher than the share of individuals with very high religious belief (Religous5) in response to earthquake $(38.5 \%)\left(\chi^{2}=9.537\right.$, $p=0.04<0.05)$, and this association in this case is moderate (Cramer's $\mathrm{V}=0.132, p=0.04<0.05)$. Following the decisions made by others is significantly associated with choosing evacuation. The share of individuals who do not have any willingness to follow decisions made by others (Follow1) shows that the probability of evacuations for this group $(38.5 \%)$ is significantly lower than the share of individuals who are following decisions made by others very high (Follow5) in response to earthquake (56.3\%) $\left(\chi^{2}=12.35, p=0.01<0.05\right)$, and this association in this case is moderate (Cramer's $\mathrm{V}=0.150, p=0.015<0.05)$. 


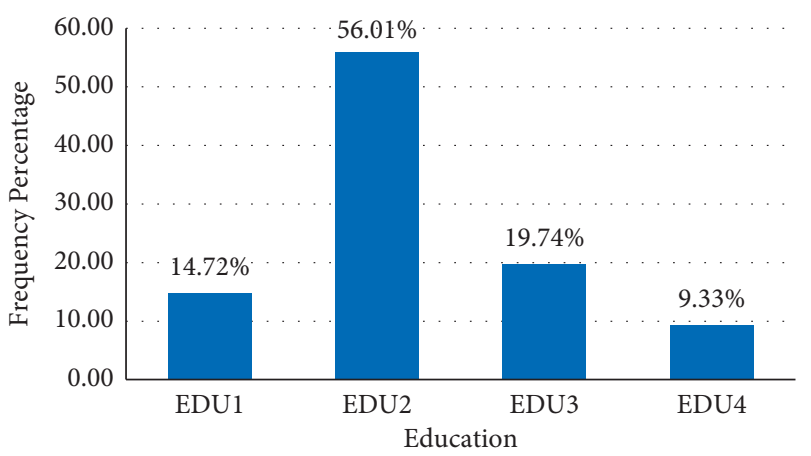

Figure 7: Frequency distribution of education variable.

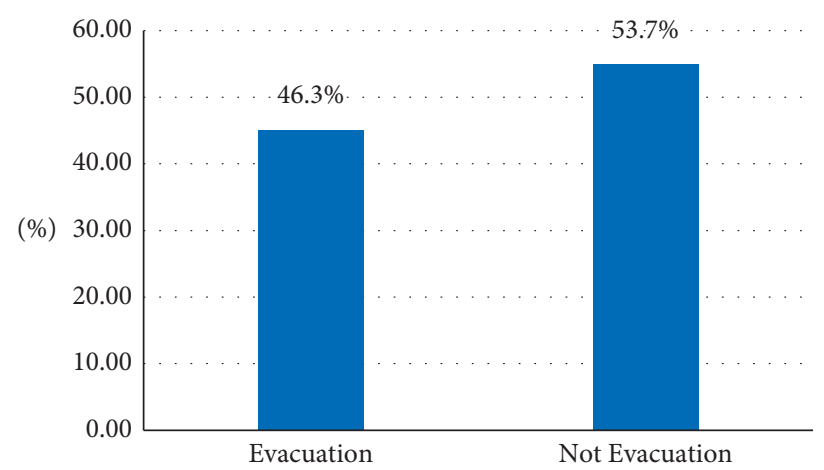

Figure 8: Percentage Frequency Distribution of Evacuation dependent variable.

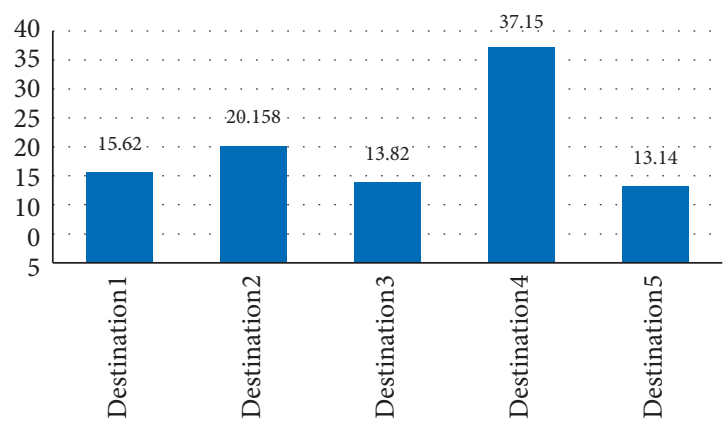

Figure 9: Percentage Frequency Distribution of Destination choice dependent variable.

Adherence to previous experiences is significantly associated with choosing evacuation $\left(\chi^{2}=15.5, p=0.001<0.05\right)$, and this association in this case is moderate (Cramer's $\mathrm{V}=0.168$, $p=0.015<0.05)$. Adherence to the acquired trainings is significantly associated with choosing evacuation $\left(\chi^{2}=28.20, p=0.00<0.05\right)$, and this association in this case is strong (Cramer's $\mathrm{V}=0.227, p=0.001<0.05$ ). Familiarity with alternative routes was significantly associated with choosing evacuation $\left(\chi^{2}=13.96, p=0.007<0.05\right)$, and this association in this case is strong (Cramer's $\mathrm{V}=0.25$, $p=0.001<0.05)$. The results of nonparametric analysis for all variable defined in the questionnaire are shown in Table 5. The values of $X^{2}, \varphi_{c}$ and Cramer's $V$ indicate that "Trip purpose" variable is not associated with evacuation variable $(p$ value $=0.124>0.1)$
4.2. Results of Evacuation Choice Model in Response to the Earthquake Disaster. The binary evacuation choice model is estimated with variables recognized as significant variables according to nonparametric variables. The estimates for the parameters of the binary evacuation choice model are presented in Table 7 . The estimation procedure is based on the maximum-likelihood approach, which maximizes the probability of a chosen alternative. The logit model results indicate that several factors will affect future evacuation behavior in response to earthquake disaster. The vector of coefficients is significantly different from zero according to the Model $\chi^{2}$ statistic. The model predicts almost $73 \%$ of the evacuations correctly. The basic test for the adequacy of the model is the examination of the values and sign of the estimates. Analyzing the estimated coefficients of the 
TABle 5: View of the database describing designated scenarios.

\begin{tabular}{lcccc}
\hline Scenario & Minor & Moderate & Severe & 0 \\
1 & 1 & 0 & 0 & 0 \\
2 & 1 & 0 & 0 & 1 \\
3 & 0 & 1 & 0 & 0 \\
4 & 0 & 1 & 1 & 1 \\
5 & 0 & 0 & 1 & 1 \\
6 & 0 & 0 & 0 & 1 \\
\hline
\end{tabular}

TABLE 6: The result of nonparametric analysis of socioeconomic/behavioral characteristics.

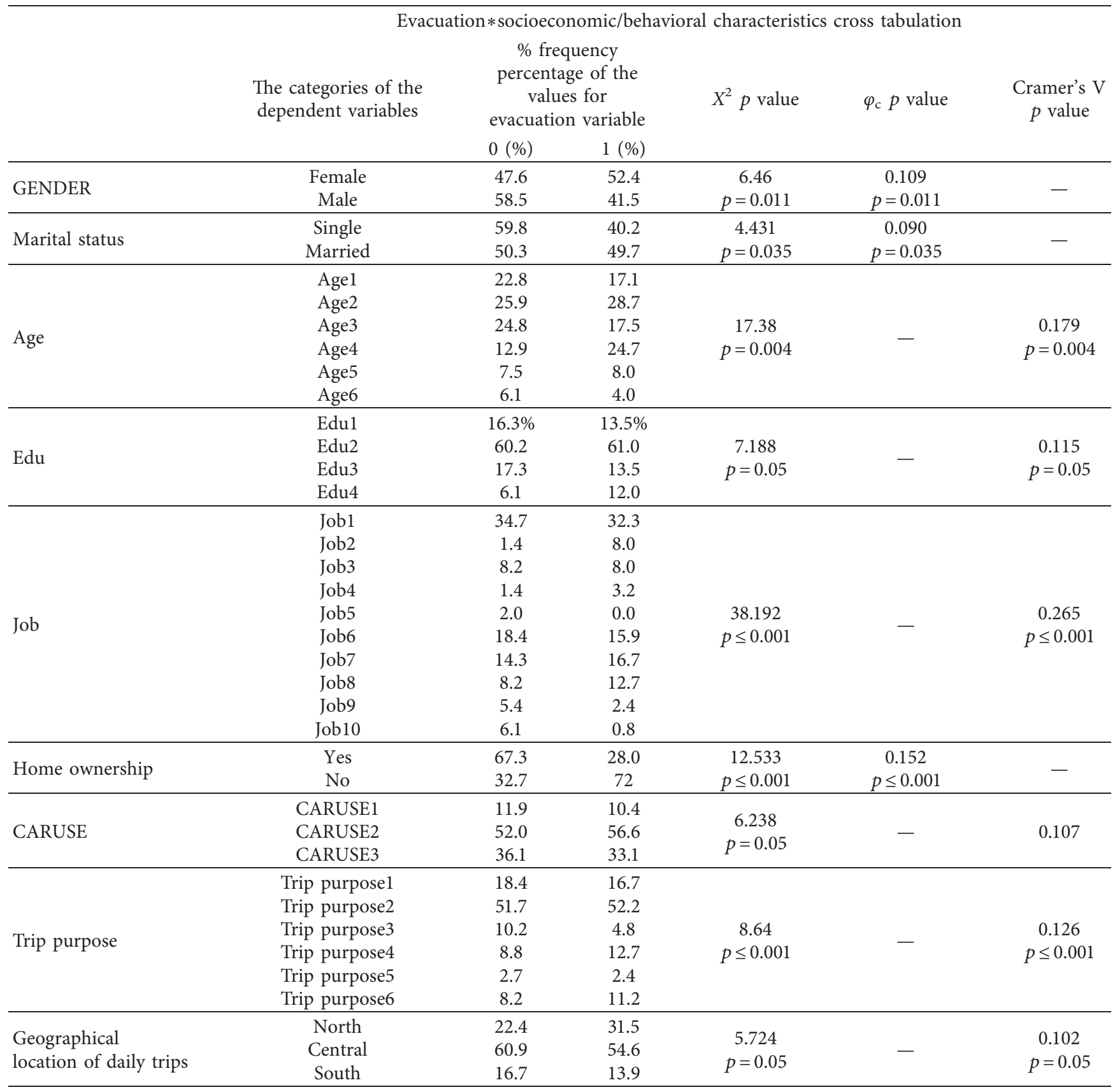


TABLE 6: Continued.

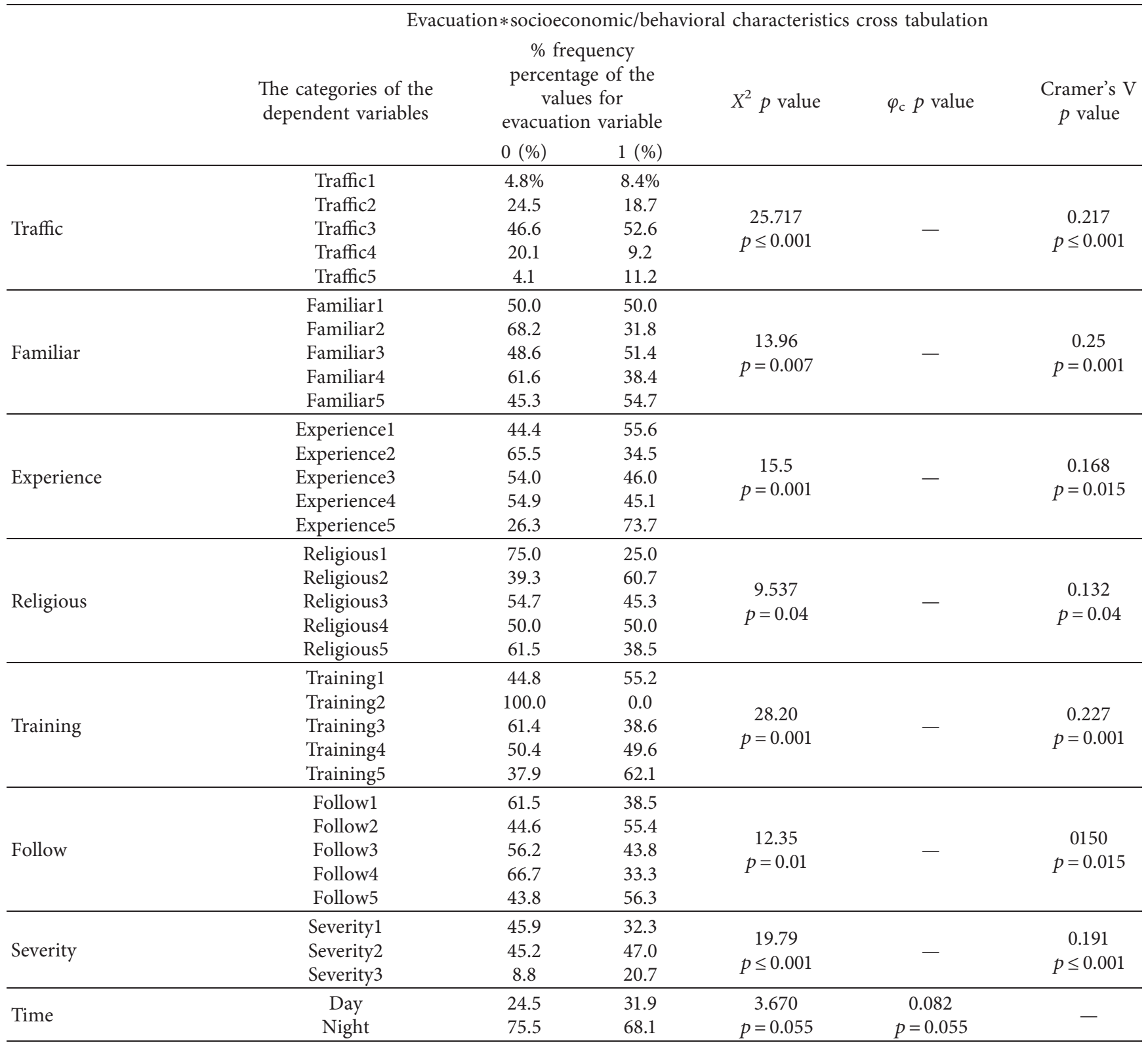

$p<0.01, p<0.05$, and $p \leq 0.10$ denote significance at $1 \%, 5 \%$, and $10 \%$ levels; $p>0.1$ : not significant.

evacuation model in response to earthquake disaster indicates the following results. The estimated coefficients for FNUM and CARNUM have positive signs, which indicate that individuals are more likely to evacuate with an increase in these variables. The t-value of the coefficients for gender, age1, age2, age3, marriage, FNUM, etc. are all significant at the $5 \%$ significance level. These findings are consistent with the findings of previous research. Dash and Gladwin [12] concluded that factors such as gender, age of the decision maker, number of family members, and income play important roles in evacuation decision-making. The negative sign of estimated coefficient for gender $(\beta=-3.471)$ indicates that men tend less to evacuate in response to an earthquake disaster. The analysis of gender shows that, in general, women have greater risk perception in situations of natural hazards [12]. Gender is often measured by evacuation studies that focus on decision-making in response to natural hazards, and the results show that female respondents are usually more likely to report having evacuated [12]. The positive sign and bigger amount of estimated coefficient for AGE2 $(\beta=20.126)$ indicate that individuals in age groups 25-32 tend more to evacuate. This finding is consistent with the results of studies by Yang et al. [8] and [14] indicated that young persons are more likely to evacuate. Similar to the study conducted by [15], the estimated coefficient for marital status $(\beta=7.633)$ states that married individuals tend more to evacuate. Protecting each other (before protecting self) is also a common explanation to the fact that married individuals were found to be more likely to evacuate in response to earthquake. The positive sign of estimated coefficient for 
TABLE 7: Result of evacuation binary logit model.

\begin{tabular}{|c|c|c|c|c|}
\hline \multirow{3}{*}{ Independent variable } & \multicolumn{4}{|c|}{ Dependent variable } \\
\hline & \multicolumn{4}{|c|}{ Evacuation } \\
\hline & Coefficient & Standard error & Wald & $p$ value \\
\hline GENDER & $-3.471^{* * *}$ & 0.620 & -5.59 & $\leq 0.001$ \\
\hline AGE1 & $15.657^{* * *}$ & 2.755 & 5.68 & $\leq 0.001$ \\
\hline AGE2 & $20.126^{* * *}$ & 3.464 & 5.81 & $\leq 0.001$ \\
\hline AGE3 & $8.917^{* * *}$ & 1.853 & 4.81 & $\leq 0.001$ \\
\hline EDU2 & $-13.348^{* * *}$ & 2.184 & -6.11 & $\leq 0.001$ \\
\hline EDU3 & $2.658^{* * *}$ & 0.859 & 3.09 & 0.0020 \\
\hline MARITAL STATUS & $7.633^{* * *}$ & 1.182 & 6.46 & $\leq 0.001$ \\
\hline JOB1 & $-8.606^{* * *}$ & 1.357 & -6.34 & $\leq 0.001$ \\
\hline JOB6 & $1.464^{* * *}$ & 0.599 & 2.44 & 0.0145 \\
\hline JOB7 & $13.117^{* * *}$ & 2.313 & 5.67 & $\leq 0.001$ \\
\hline HOME OWNERSHIP & $-2.251^{* * *}$ & 0.581 & 3.23 & $\leq 0.001$ \\
\hline FNUM & $0.919^{* * *}$ & 0.247 & 3.71 & 0.0002 \\
\hline CARNUM & $4.166^{* * *}$ & 0.807 & 5.16 & $\leq 0.001$ \\
\hline CARUSE2 & $1.083^{* * *}$ & 0.472 & 2.29 & 0.0220 \\
\hline CARUSE3 & $7.260^{* * *}$ & 1.276 & 5.69 & $\leq 0.001$ \\
\hline NORTH & $-7.061^{* * *}$ & 1.306 & -5.40 & $\leq 0.001$ \\
\hline CENTRALS & $-17.11^{* * *}$ & 2.937 & -5.83 & $\leq 0.001$ \\
\hline TRAFFIC2 & $-11.102^{* * *}$ & 2.037 & -5.45 & $\leq 0.001$ \\
\hline TRAFFIC3 & $-3.935^{* * *}$ & 0.784 & -5.01 & $\leq 0.001$ \\
\hline FAMILIAR2 & $-2.860^{* * *}$ & 0.594 & -4.81 & $\leq 0.001$ \\
\hline FAMILIAR3 & $3.820^{* * *}$ & 0.794 & 4.81 & $\leq 0.001$ \\
\hline FAMILIAR4 & $3.999^{* * * *}$ & 0.903 & 4.43 & $\leq 0.001$ \\
\hline EXPERIENCE 3 & $3.796^{* * *}$ & 0.657 & 5.77 & $\leq 0.001$ \\
\hline RELIGIOUS3 & $-2.296^{* * *}$ & 0.488 & -4.70 & $\leq 0.001$ \\
\hline TRAINING3 & $5.914^{* * *}$ & 1.017 & 5.81 & $\leq 0.001$ \\
\hline FOLLOW3 & $0.743^{*}$ & 0.897 & -4.80 & 0.0655 \\
\hline SEVERITY1 & $-0.914^{* *}$ & 0.628 & -1.46 & 0.0552 \\
\hline SEVERITY2 & $3.837^{* * *}$ & 0.815 & -4.71 & $\leq 0.001$ \\
\hline SEVERITY3 & $12.712^{* * *}$ & 2.471 & 5.14 & $\leq 0.001$ \\
\hline TIME & $0.217^{* *}$ & 0.099 & 2.19 & 0.0283 \\
\hline Log likelihood function & \multicolumn{4}{|c|}{-1259.462} \\
\hline Chi-squared & \multicolumn{4}{|c|}{510.626} \\
\hline Significance level & \multicolumn{4}{|c|}{$\leq 0.001$} \\
\hline Prob > Chi2 $\left(\chi^{2}\right)$ & \multicolumn{4}{|c|}{$\leq 0.001$} \\
\hline Pseudo $R^{2}$ & \multicolumn{4}{|c|}{0.168} \\
\hline
\end{tabular}

${ }^{* * *},{ }^{* *}$, and ${ }^{*}$ denote significance at $1 \%, 5 \%$, and $10 \%$ level. Bold values indicate model fit indices. For example: Log likelihood function is a measure of how well a particular model fits the data and the chi-squared statistic is a test that measures how a model compares to actual observed data.

EDU3 $(\beta=2.658)$ indicates that as the level of education increases, the tendency to evacuate is more. The same study also reported that participants with a higher education had a greater tendency to evacuate [15]. The negative sign of estimated coefficient for home ownership $(\beta=-2.251)$ indicates that people who own their homes are less likely to evacuate. This result is in consistence with the result of Solís et al. [13] that indicated that homeowners are less likely to evacuate [13]. As the number of family members increases, the tendency to evacuate after the earthquake disaster increases $(\beta=0.919)$. In the research of Lee et al., it is also found that the household size is an influential factor when an evacuation decision is made [30]. They concluded that if there are over three members in a household, people are more likely to evacuate during emergencies. Also, this result is in accordance with the study of Cutter and Barnes [30]. As the number of family car ownership increases, the willingness to evacuate after the earthquake disaster increases $(\beta=4.166)$. It will be more willing to evacuate by increasing the number of car ownership since people have all the necessary means to evacuate in a convenient way. The negative sign of estimated coefficient $(\beta=-11.102)$ indicates that individuals facing congested traffic on their daily trips have less tendency to go out of the building and evacuate. It can be because facing congested traffic increases the sense of being blocked and prevents evacuation. The negative sign of estimated coefficient for familiar2 $(\beta=-2.860)$ indicates that individuals unfamiliar with alternative routes in their daily trips have less tendency to go out of the building and evacuate, while as the familiarity with alternative routes becomes more, the tendency to evacuate increases. This finding is in consistence with the fact that being familiar with alternative routes and escape ways increases the probability of evacuation. The negative sign of estimated coefficient for Religious3 $(\beta=-2.296)$ indicates that individuals with moderate religious beliefs tend less to evacuate and go out of 


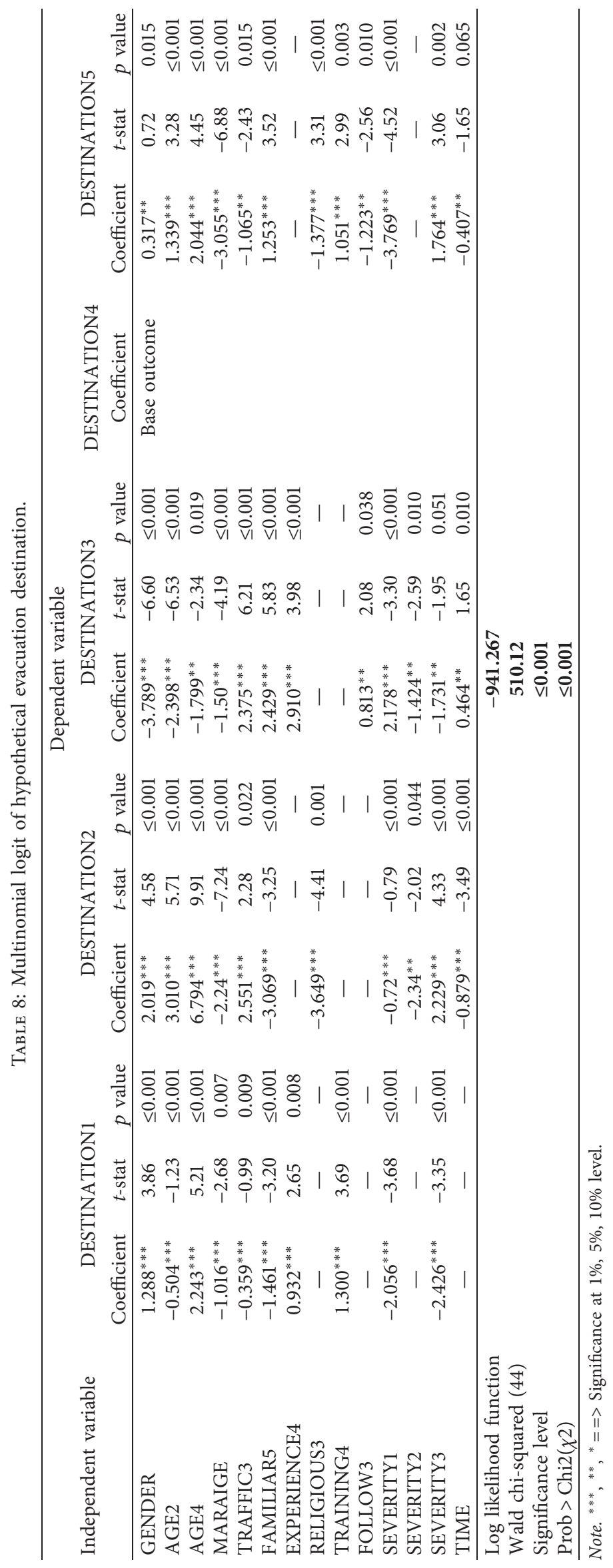


the building. It can be concluded that religious beliefs lead individuals more to believe in fate and prevent them from attempting evacuation. Individuals who follow previous experiences $(\beta=3.796)$, acquired trainings $(\beta=5.914)$, and decisions made by others $(\beta=0.743)$ moderately are more likely to evacuate. It can be concluded that the effects of studying the behavior of individuals in response to previous experiences, training the necessary knowledge to confront emergency situation, and studying the collective behavior are extremely effective information in predicting decisionmaking and managing disasters. To study the effect of six designated earthquake scenarios at different severities (Minor, Moderate, and Severe) and times (Day, Night), the estimated coefficients of the "Severity1," "Severity2," "Severity3," and "Time" variables in the logit model are interpreted. As expected, the estimated coefficients for severity variables indicate that as the earthquake severity increases, the tendency to evacuate increases. Also, in the earthquakes occurring at night, individuals have more tendency to evacuate.

\subsection{Results of Destination Choice Model in Response to the} Earthquake Disaster. The hypothetical evacuation destination choice is modeled with the multinomial logit model (Table 8). The sample includes all those households who state that they would evacuate in the hypothetical earthquake $(n=253)$. The multinomial logit model assesses the probability that each destination will be chosen relative to evacuating to urban open spaces (Destination4). The overall model is statistically significant according to the Model $\chi 2$ statistic. According to the interpretation of the estimated coefficients of dependent variables for the destination choice model in response to the earthquake disaster, respondents who are male and are in the age group 46-55 are more likely to choose gas station destination rather than go to urban open spaces. Married respondents are less likely to choose a gas station. Households who face normal traffic in daily trips and are completely familiar with alternative routes are less likely to choose gas station relative to urban open spaces destination, while households following previous experiences and acquired training highly are more likely to choose gas station relative to urban open spaces destination. In minor and severe severity of earthquakes, individuals are less likely to choose gas station destination rather than going to urban open spaces. Women respondents and individuals in age group 25-32 and 46-55 are more likely to choose going to service and relief centers rather than going to urban open spaces. Married individuals and respondents with moderate religious beliefs who are completely familiar with alternative routes are less likely to choose going to service and relief centers rather than going to urban open spaces. While individuals who face normal traffic in daily trips are more likely to go service and relief centers. In minor and moderate severity of earthquakes, individuals are less likely to choose the service and relief centers destination, while, in severe earthquakes because of probable injuries, they are more likely to choose the service and relief centers destination rather than going to urban open spaces. Respondents who are male and married are less likely to choose going to relative's home destination rather than going to urban open spaces. Respondents facing normal traffic in daily trips, who are completely familiar with alternative routes, following previous experiences highly, and following decisions made by others moderately are more likely to choose going to relative's home destination. In moderate and severe severity earthquakes, respondents are less likely to go to relative's home, while, in minor severity earthquakes, they are more likely to go to relative's home. Male respondents are more likely to choose going out of the city destination. Married respondents are less likely to choose going out of the city destination. Respondents who are completely familiar with alternative routes and following acquired training highly are more likely to choose going out of the city destination rather than going to urban open spaces, while respondents with moderate religious beliefs and following decisions made by others moderately are less likely to go out of city to a relative rather than going to urban open spaces. In minor severity earthquakes, respondents are less likely to choose going out of the city destination, while, in severe severity earthquakes, individuals are more likely to go out of city. If the earthquake occurred at night, households are less likely to choose the service and relief centers and going out of city, while they are more likely to choose a relative's home.

\section{Conclusion}

In this study, the impact of socioeconomic variables, the daily trips characteristics, and behavioral factors on travel choice behavior in two stages of decision-making including evacuation and destination choice are studied by using discrete choice modeling. The SP method was used for data collection. Data were collected from field survey assuming the hypothetical earthquake scenarios for the City of Qazvin. The questionnaire is designed in the form of six scenarios including three earthquake severities (minor, moderate, and severe) during the time of day and night. In this section, the conclusions and suggestions for future researches are presented. This study develops binary logit models for evacuation choice behavior in response to earthquake disaster. The analysis of collected data identifies gender, age, education, marital status, job, home ownership, number of family members, and number of car ownership as significant factors influencing evacuation choice in response to earthquake disaster. In addition, the daily trips characteristics such as geographical location of daily trips, traffic condition in daily trips, and familiarity with alternative routes are significant in evacuation choice model. Furthermore, the analysis of behavioral factors indicates that religious belief, following decisions made by others, adherence to previous experiences, and adherence to the acquired trainings are significantly associated with evacuation choice. The binary model depicts that marital status, age, family size, and number of car ownership have positive effects on evacuation choice in response to earthquakes. It can be concluded that married individuals, people in age group 25-32, and families with more members and car ownership are more concerned about the after effect of earthquakes, and they have more preparedness for evacuation. On the other hand, gender has a negative effect on the utility to choose evacuation as a 
choice behavior in response to earthquakes. It can be because women perceive risks differently, and they are more likely to evacuate. People who own their homes are less likely to evacuate. It can be because of their concern about the safety of the belongings.

This study concludes that the moderate religious belief is the reason of reducing the likelihood of evacuation. Also, individuals who follow previous experiences and trust in acquired trainings and decisions made by others moderately are more likely to evacuate. These results indicate the importance of training and providing the necessary knowledge to confront the earthquake disaster. As expected, the study finds out that the probability to choose evacuation increases with the severity of the earthquake. In the earthquakes occurring at night, the tendency to evacuate is more because of the fear of trapping.

In terms of destination choice behavior, the results indicate that, in contrast to going to urban open spaces, men are more likely to go to gas stations, service and relief centers, and out of city, while they are less likely to go to a relative's home. Married individuals are less likely to choose other destinations versus going to urban open spaces. Individuals facing normal traffic on their daily trips are less likely to go gas stations and out of the city versus going to urban open spaces. Individuals following previous experiences highly are more likely to choose gas station and relative's home destination versus going to urban open spaces. Individuals with moderate religious beliefs are less likely to go service and relief centers and out of city relative to urban open spaces destination. People who follow others moderately in their decisions tend more to go relative's home, while they tend less to go out of city versus going to urban open spaces. In earthquakes occurring with minor severity, individuals are less likely to go to other destinations, while, in severe earthquakes, the tendency to go out of the city and go to service and relief centers is more versus going to urban open spaces. At night, individuals are more likely to choose relative's home destination rather than urban open spaces.

This study helps planners plan facilities in the event of a natural disaster. The discrete choice model identifies the factors affecting the evacuation decision of Qazvin residents. Results can be useful for government agencies as a guidance in managing and planning disaster evacuation in transportation network in the future. Future improvements will include gathering more information about personality traits and other evacuation decision-making variables. Incorporation of hypothetical scenarios for two seasons, summer and winter time, can be another extension of the future work.

\section{Data Availability}

The excel data used to support the findings of this study are available from the corresponding author upon request.

\section{Conflicts of Interest}

The authors declare that they have no conflicts of interest.

\section{References}

[1] M. Ibrion, M. Mokhtari, and F. Nadim, "Earthquake disaster risk reduction in Iran: lessons and "lessons learned" from three large earthquake disasters-Tabas 1978, Rudbar 1990, and Bam 2003," International Journal of Disaster Risk Science, vol. 6, no. 4, pp. 415-427, 2015.

[2] A. Edrissi, H. Poorzahedy, H. Nassiri, and M. Nourinejad, "A multi-agent optimization formulation of earthquake disaster prevention and management," European Journal of Operational Research, vol. 229, no. 1, pp. 261-275, 2013.

[3] B. Lee, Z. Zheng, S. A. Kashfi, J. C. S. Chia, and R. Yi, "Observation of bus ridership in the aftermath of the 2011 floods in southeast Queensland, Australia," in Proceedings of the 9th Annual International Conference of the International Institute for Infrastructure Renewal and Reconstruction, pp. 382-390, Queensland University of Technology, Brisbane, Australia, 2015.

[4] L. Chang, Transportation system modelling and applications in earthquake engineering, Ph.D. thesis, University of Illinois at Urbana-Champaign, Champaign, IL, USA, 2010.

[5] D. Oshima, S. Tanaka, and T. Oguchi, "Evaluation of traffic control policy in disaster case by using traffic simulation model," in Proceedings of the 19th ITS World Congress, pp. 22-26, Vienna, Austria, 2012.

[6] D. Tuzun Aksu and L. Ozdamar, "A mathematical model for post-disaster road restoration: enabling accessibility and evacuation," Transportation Research Part E: Logistics and Transportation Review, vol. 61, pp. 56-67, 2014.

[7] J. Richard Eiser, A. Bostrom, I. Burton et al., "Risk interpretation and action: a conceptual framework for responses to natural hazards," International Journal of Disaster Risk Reduction, vol. 1, pp. 5-16, 2012.

[8] H. Yang, E. F. Morgul, K. Ozbay, and K. Xie, "Modeling evacuation behavior under hurricane conditions," Transportation Research Record: Journal of the Transportation Research Board, vol. 2599, no. 1, pp. 63-69, 2016.

[9] E. J. Baker, "Hurricane evacuation behavior," International Journal of Mass Emergencies and Disasters, vol. 9, no. 2, pp. 287-310, 1991.

[10] J. Whitehead, B. Edwards, M. Vanwilligen, J. Maiolo, K. Wilson, and K. Smith, "Heading for higher ground: factors affecting real and hypothetical hurricane evacuation behavior," Global Environmental Change Part B: Environmental Hazards, vol. 2, no. 4, pp. 133-142, 2000.

[11] J. M. Bateman and B. Edwards, "Gender and evacuation: a closer look at why women are more likely to evacuate for hurricanes," Natural Hazards Review, vol. 3, no. 3, pp. 107-117, 2002.

[12] N. Dash and H. Gladwin, "Evacuation decision making and behavioral responses: individual and household," Natural Hazards Review, vol. 8, no. 3, pp. 69-77, 2007.

[13] D. Solís, M. Thomas, and D. Letson, "An empirical evaluation of the determinants of household hurricane evacuation choice," Journal of Development and Agricultural Economics, vol. 2, no. 5, pp. 188-196, 2010.

[14] D. Deka and J. A. Carnegie, "Forecasting shelter accessibility and vehicle availability for hurricane evacuation in northern New Jersey using sample enumeration," International Journal of Mass Emergencies and Disasters, vol. 30, no. 3, 2012.

[15] S. Shapira, L. Aharonson-Daniel, and Y. Bar-Dayan, "Anticipated behavioral response patterns to an earthquake: the role of personal and household characteristics, risk 
perception, previous experience and preparedness," International Journal of Disaster Risk Reduction, vol. 31, pp. 1-8, 2018.

[16] M. B. B. Lim, H. R. Lim Jr, and M. Piantanakulchai, "Flood evacuation decision modeling for high risk urban area in the Philippines," Asia Pacific Management Review, vol. 24, no. 2, pp. 106-113, 2019.

[17] T. Phiophuead and N. Kunsuwan, "Logistic regression analysis of factors affecting travel mode choice for disaster evacuation," Engineering Journal, vol. 23, no. 6, pp. 399-417, 2019.

[18] K. E. Train, Discrete Choice Methods with Simulation, Cambridge University Press, Cambridge, UK, 2009.

[19] S. Tanaka, M. Kuwahara, T. Yoshii, R. Horiguchi, and H. Akahane, "Estimation of travel demand and network simulators to evaluate traffic management schemes in disaster," in Proceedings of the INCEDE-NCEER Center-toCenter Project Workshop in Earthquake Engineering-Frontiers in Transport Systems, pp. 1-16, Tokyo, Japan, 2001.

[20] N. N. Ambraseys and C. P. Melville, A History of Persian Earthquakes, p. 219, Cambridge University Press, Cambridge, UK, 1982.

[21] N. A. Comijany, A. A. Fard, and M. Pourkermani, "An overview of seismic hazard of Qazvin City and comparison with Iranian code of practice for resistant design of buildings," Journal of Sciences (Islamic Azad University), vol. 23, no. 89, 2013.

[22] Noandishaan Consulting Engineers, Comprehensive Plan of Qazvin City, Housing and Urban Development Organization, Qazvin, Iran, 2014.

[23] R.-C. Jou and K.-H. Chen, "An application of cumulative prospect theory to freeway drivers' route choice behaviours," Transportation Research Part A: Policy and Practice, vol. 49, pp. 123-131, 2013.

[24] W. G. Cochran, Sampling Techniques, John Wiley \& Sons, New York, NY, USA, 2nd edition, 1963.

[25] L. J. Cronbach and R. J. Shavelson, "My current thoughts on coefficient alpha and successor procedures," Educational and Psychological Measurement, vol. 64, no. 3, pp. 391-418, 2004.

[26] S. M. Hosseinian, V. Najafi Moghaddam Gilani, B. Mirbaha, and A. Abdi Kordani, "Statistical analysis for study of the effect of dark clothing color of female pedestrians on the severity of accident using machine learning methods," Mathematical Problems in Engineering, vol. 2021, Article ID 5567638, 21 pages, 2021.

[27] G. W. Corder and D. I. Foreman, Nonparametric Statistics: A Step-by-step Approach, John Wiley \& Sons, New York, NY, USA, 2014.

[28] D. J. Sheskin, Handbook of Parametric and Nonparametric Statistical Procedures, CRC Press, Boca Raton, FL, USA, 1997.

[29] D. Lee, S. Yoon, E.-S. Park, Y. Kim, and D. K. Yoon, "Factors contributing to disaster evacuation: the case of South Korea," Sustainability, vol. 10, no. 10, p. 3818, 2018.

[30] S. Cutter and K. Barnes, "Evacuation behavior and three mile island," Disasters, vol. 6, no. 2, pp. 116-124, 1982. 